\title{
Assessment of Sous Vide Knowledge and Inspection/Cooking Practices
}

\author{
Chen Huang ${ }^{1}$, Helen Heacock ${ }^{2}$, Lorraine Mclntyre $^{3}$ \\ ${ }^{1}$ Lead Author and Researcher, B. Tech Student, School of Health Science, British Columbia Institute of Technology, \\ 3700 Willingdon Ave, Burnaby, BC V5G 3H2 \\ ${ }^{2}$ Supervisor, School of Health Science, British Columbia Institute of Technology, 3700 Willingdon Ave, Burnaby, BC \\ V5G 3H2 \\ ${ }^{3}$ Contributor, British Columbia Centre for Disease Control, 655 West $12^{\text {th }}$ Ave, Vancouver, BC, V5Z 4R4
}

\begin{abstract}
:
Background: In September 2014, BCCDC developed “Guidelines for Restaurant Sous Vide Cooking Safety in British Columbia” providing Environmental Health Officers (EHO) and sous vide cooking chefs safety knowledge about sous vide cooking. To assess whether the guidelines improved sous vide safety knowledge, a study was conducted to examine and compare knowledge differences between EHOs and chefs who had read the guidelines to those who had not read the guidelines.
\end{abstract}

Methods: An online survey was created and advertised by publishing on the BCCDC website, in newsletters and magazines (Vancouver Costal Health newsletter, Fraser Health news Letter, Chefs Quarterly magazine), and through e-mail distribution lists to EHOs and chefs, including chefs at Vancouver Community College. The questions in this survey were developed based on the guidelines. T-tests and Chi square analyses were conducted to assess knowledge difference between those who read the guidelines and those who did not.

Results: A total of 65 people completed the survey, including 45 EHOs (69.3\%), 15 chefs (23\%), and 5 others (7.7\%). EHOs who read the guidelines had significantly higher average knowledge scores in the multiple choice section of the sous vide safety knowledge survey ( $\mathrm{p}=0.00028, t$-test) when compared to EHOs who had never read the guidelines. No differences were found in the true and false section ( $\mathrm{p}=0.43925, t$-test). With regard to inspection practices, EHO who read the guidelines were more likely to frequently check for the internal temperature of sous vide foods, water bath temperature, time/temperature in the recipes, calibration of thermometer and proper labels on sous vide pouched foods than EHOs who never read the guidelines. Chefs who read the guidelines had similar average score as chefs who never read the guidelines in $\mathrm{T} / \mathrm{F}$ ( $\mathrm{p}=0.79878, t$-test) and multiple choice ( $\mathrm{p}=0.97, t$-test). With regard to cooking practice, chefs who read the guidelines were more likely to frequently calibrate thermometers than chefs who never read the guidelines. However, chefs who never read the guidelines were more likely to frequently find their sous vide pouch floating during the cooking process, to check for internal temperature of sous vide food, and to label their sous vide pouch properly.

Conclusion: These results show that EHOs who have read the sous vide guidelines have better sous vide knowledge in comparison to EHOs who have never read the guidelines. They are also more likely to have overall better inspection practices. Nevertheless, results show chefs who read the guidelines have similar sous vide knowledge in comparison to chefs who never read the guidelines. In terms of cooking practices, these chefs are likely to have better cooking practices only in certain areas.

Key words: survey, sous vide, guideline, inspection/cooking practices 


\section{Introduction}

This project assessed of knowledge and training of sous vide cooking chefs and Environmental Health Officers (EHO). It was suggested by a food specialist from the British Columbia Centre for Disease Control (BCCDC), Lorraine Mclntyre. The sous vide cooking style can be found in high-end restaurants in BC and it is increasingly popular as more people are willing to try these novel foods and more chefs are preparing foods using sous vide style methods. This also means safety of sous vide foods is becoming a public health concern. Sous vide is relatively new and unique cooking method. In addition, chefs may have different secret sous vide recipes and different process paths to prepare these foods. Thus, ensure safety of food, sufficient knowledge and training in the sous vide cooking style as well as thorough understanding of risks involved in sous vide are required from chefs and EHOs.

\section{What is sous vide?}

The term sous vide, in French, means under vacuum. Generally speaking, the process of sous vide includes: (i) preparing raw ingredients, (ii) the vacuum sealing of foods, (iii) cooking/heating step, (iv) the hot-holding of foods, and (v) one or more chill steps in the process. (BCCDC, 2014) It is a unique cooking method that generally prepares food at lower temperature for longer periods of time in a sealed plastic bag through immersion in a water bath. This method has also been described as the LT LT (low-temperature long-time) cooking practice. (BCCDC, 2014)

\section{Advantages of sous vide}

Meats prepared in this way are able to retain their moisture, tenderness, and flavors (NAC, 2008) because the low temperature "breaks down collagen in connective tissue" without changing the texture toughness and moisture of the meat's protein. (CFIA, 2010) Another ad- vantage of sous vide cooking is that it helps add flavour into the meat. By simply adding ingredients such as garlic, butter or herbs into the bag, the flavour will penetrate the whole meat. (Logsdon, 2014)

The sous vide cooking style also allows the chef to precisely control the temperature of food. The conventional cooking method usually performs under high heat condition. During the cooking process, food is cooked at a temperature that is "much higher than desired internal temperature of the food". (Ruiz, 2013) Thus, it is critical to remove food from heat at the right timing. If food is removed too early, the food will be undercooked. If removed too late, the food will be overcooked. In the process of sous vide cooking, the plastic bag containing food is placed in a water bath for gentle heating. The temperature of the water bath is "set at the desired final internal cooking temperature of the food". (Ruiz, 2013) This ensures that the food will be heated to the desired temperature, and the food will not be overcooked as it "can't get hotter than the water bath”. (Ruiz, 2013) With sufficient cooking time provided, the food will not be undercooked either. (Ruiz, 2013)

Depending on the items, cooking times vary quite significantly. For example, a thin item, a fish cut for instance, takes only a few minutes to cook while thick items like beef brisket or short ribs may take even up to 72 hours cook at $55^{\circ} \mathrm{C}$. (Ruiz, 2013) Vegetables are generally “cooked at $85^{\circ} \mathrm{C}$ for 1 to 2 hours”. (Ruiz, 2013) Such long hours of cooking at lower temperature helps maintain "the colour of meat and gives vegetable an al dente feel”. (Ruiz, 2013)

\section{Equipment}

The equipment used in sous vide typically includes "a temperature controlled water bath, a probe thermometer, a vacuum sealer and water impermeable heat stable plastic pouches”. (Ruiz, 2013) Different brands may be of varying cost 
and quality. In order to control and monitor the temperature effectively, it is recommended to use "a circulating water bath and a thermometer capable of measuring to 0.1 degree Celsius”. (Ruiz, 2013)

\section{Microbiological Hazards}

Microbiological hazards, including bacteria, viruses, and parasites, are always the biggest concern in food safety. (Sivapalasingam, 2004) Some of these hazards are normally present in food. This includes Salmonella in raw poultry, Escherichia coli 0157:H7 in raw beef; and Listeria monocytogenes in seafood. (Duffy et al, 2006) These pathogens are able to cause illnesses such as typhoid fever (Salmonella), hemolytic-uremic syndrome (E. coli), and meningitis in newborns (Listeria). (Ryan, 2004) In addition, the presence of parasites in meats also occurs naturally. (BCCDC, 2014) Anasakids or Diphyllobothrium worms can be found "commonly in fresh fish" whereas Trichinella exists in "wild game meat such as bear”. (BCCDC, 2014) Since these meats are the common ingredients of sous vide cooking, to avoid any potential foodborne illness, obtaining these ingredients from an approved source and proper refrigeration of raw ingredients are the first important control points for food safety. (BCCDC, 2014) A study has found that low quality raw food has higher numbers of bacteria counts and, therefore, requires longer cooking period at higher temperatures. (Snyder, 2004) Nevertheless, the sous vide LT LT cooking method may not be sufficient to ensure safety of low quality food. (BCCDC, 2014) Thus, getting high quality food ingredients and maintaining such quality before cooking is crucial to public health.

During the sous vide cooking process, microbiological hazards can also be introduced onto the food in different ways, including crosscontamination and poor food handling practices. Cross-contamination can occur when finished food comes in contact with raw food. This al- lows pathogens to move from raw food onto finished food, resulting in foodborne illnesses. Poor food handling practice is also another way that pathogens can get into food. For instance, an infected food handler can introduce viruses, such as norovirus, "through unsanitary handling of food”. (BCCDC, 2014) Also, just like the meats, the human body is also able to carry microbiological hazards naturally. For instance, Staphylococcus aureus which can cause food poisoning is commonly found in the nasal cavities of $50 \%$ of health adults. (Frank, 2010) E. coli O157:H7 can cause hemolytic-uremic syndrome (HUS) and can be found in the large intestine. (Rasko, 2011) Without proper food handling practices, such as proper hand-washing, these microbiological hazards can move from food handlers onto the food eventually causing foodborne illness. (BCCDC, 2014)

Once they have been introduced onto food, pathogens can grow and multiply under the right condition. The method of sous vide cooking provides an anaerobic condition at around $55^{\circ} \mathrm{C}$ $\sim 70^{\circ} \mathrm{C}$. (BCCDC, 2014) Under this condition, the bacteria of most concern are "the ones that can grow in the absence of oxygen, form spores, or multiply at temperature that is close to $55^{\circ} \mathrm{C}$." (Christensen, 2012)

In an anaerobic environment, anaerobic bacteria and facultative anaerobic bacteria such as Clostridium botulinum and Clostridium perfingens are able to survive. In foods, C. botulinum is of concern as it is able to germinate and produce deadly toxin between $3.3^{\circ} \mathrm{C}$ and $45^{\circ} \mathrm{C}$ in the absence of oxygen. The botulinum toxin is a type of neurotoxin. A study has shown that one teaspoon of the botulinum toxin is enough to kill 100,000 adults. (Horowitz, 2005) In the past, several botulinum toxin outbreaks have occurred caused by temperature abused canned/packaged food. (Juliao, 2013) To inhibit the toxin production, having proper temperature control is critical. The sous vide vacuum-packaged food generally should be kept at $3^{\circ} \mathrm{C}$ or below. (BCCDC, 
2014) If the food is not served right away after sous vide pasteurization, it is recommended "to cool foods to below $3^{\circ} \mathrm{C}$ within 2 hours”. (The Culinary Institute of America, 2011) In addition to botulinum, other bacteria that can survive under the anaerobic condition include Salmonella, Bacillus cereus, Listeria, Yersinia enterocolitica, Vibrio spp. and E. coli O157:H7. (BCCDC, 2014)

The heat applied during sous vide cooking is sufficient to kill most vegetative bacteria. However, the spore-forming bacteria, such as $B$. cereus, and $C$. perfringens are able to survive through such a cooking step. (BCCDC, 2014) Under a nutrient deprivation condition, the spore-forming bacteria form endospores which are resistant to UV, high/low temperature, chemical disinfectants, and enzymatic destruction. (McKenney, 2012) The endospores allow bacteria to remain at their dormant state for long period of time until the surrounding environment becomes favourable. Most endospores germinate between $6{ }^{\circ} \mathrm{C}$ and $41{ }^{\circ} \mathrm{C}$. (Snyder, 2004). Just like $C$. botulinum, the result of germination is the production of toxin. $B$. cereus grows optimally at $30^{\circ} \mathrm{C}$ and produces two types of toxins, a heat-labile enterotoxin and a heatstabile emetic toxin (cereulide). (Wijnands, 2006) C. perfringens which grows optimally at $37^{\circ} \mathrm{C}$ can also produce enterotoxin. These toxins caused foodborne illnesses resulting symptoms such as cramps, nausea, vomiting or diarrhea. (US CDC) Foodborne illness caused by $C$. perfringens is very common. In the US, it has been reported that " $C$. perfringens causes nearly one million cases of foodborne illness each year”. (US CDC)

To prevent these toxins occurring from the germination of endospores, once again, having proper temperature and time control is crucial. In general, the food should be kept out of the temperature range that favors the process of germination as much as possible. That means all sous vide processing steps, including cooking, cooling, warming, hot-holding, and reheating, should be carefully performed in order to avoid toxin production. For instance, during sous vide cooking, it is necessary to ensure "the intended internal temperature" of the food is reached within certain time period, and then is "held long enough to achieve full pasteurization". (BCCDC, 2014) In terms of cooling, the Food Retail and Food Services Code (FRFSC) requires food to be cooled from $60^{\circ} \mathrm{C}$ to $4^{\circ} \mathrm{C}$ within 6 hours. (FRFSC, 2004) However, since most of sous vide food is cooked to only $55^{\circ} \mathrm{C}$, as suggested above, "sous vide food should be cooled within 2 hours to below $3{ }^{\circ} \mathrm{C}$, using a 50:50 ice water bath”. (The Culinary Institute of America, 2011) In terms of warming and hotholding, the sous vide pasteurized food can only be warmed for immediate consumption. (BCCDC, 2014) Furthermore, if the sous vide pasteurized food is warmed at more than $55^{\circ} \mathrm{C}$ during the warming process, it can be held for more than 2 hours. If, however, this food is warmed at less than $55^{\circ} \mathrm{C}$, it should be held for less than 2 hours. (BCCDC, 2014) Based on the food code, the general standard for hot-holding temperature is $60^{\circ} \mathrm{C}$. (FRFSC, 2004) Nevertheless, the sous vide fully pasteurized food that is held within vacuum pouch is exempted from this requirement as it has been shown that "food held above $54.4^{\circ} \mathrm{C}$ has control on $C$. perfringens growth”. (Snyder, 2004)

By identifying these potential bacterial hazards related to sous vide, control points and critical control points (CCPs) of sous vide cooking process can be determined. Developed by BCCDC, Table 1 lists out potential bacterial hazards in each sous vide cooking step and a method to reduce or limit these hazards.

\section{Temperature safety zones}

In conventional cooking systems, a temperature range between $4^{\circ} \mathrm{C}$ and $60^{\circ} \mathrm{C}$ is known as the danger zone. Within the danger zone, pathogen 
capable of causing foodborne illness can grow and multiply. However, a lot of sous vide dishes are prepared at only $55^{\circ} \mathrm{C}$ which is still within the danger zone. Nevertheless, given its unique style of cooking, the concept of danger zone is not applicable in sous vide without adjustment. Because of this, BC CDC has adopted a new concept of “danger zone” from a blog site for sous vide, shown in figure 1. (Francois, 2013)

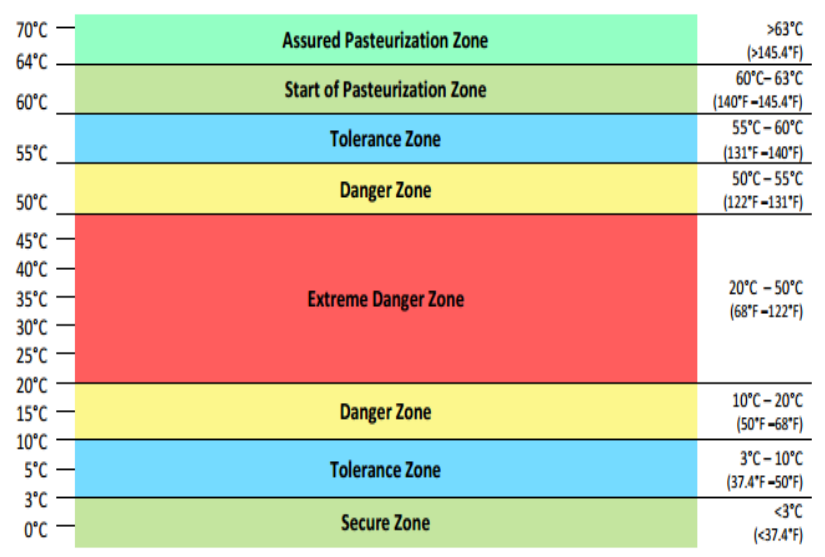

Figure 1-Sous vide temperature safety zones

According to figure 1 , the new danger zone ranges from $10^{\circ} \mathrm{C}$ to $55^{\circ} \mathrm{C}$. If the food is prepared by following an approved sous vide recipe, cooking at $55^{\circ} \mathrm{C}$ is now safe for human consumption.

\section{Time requirement}

As mentioned above, sous vide cooking has a relatively longer cooking period. From a food hygiene perspective, the amount of time required to cook an item thoroughly is determined by the amount of bacteria reduced in food. In the US and Canada, most current regulations and guidelines suggest a minimum 6.5$\log$ reduction in bacteria for all pasteurized foods, and a 7-log reduction in bacteria for poultry. (CFIA, 2010)(FDA, 2013) In order to meet the basic requirement, different amount of time may be required for cooking the same item, depending on the temperature. Developed by BC CDC, Table 3 lists out the amount of time that is required to achieve 6.5-log reduction in Salmonella for pasteurized foods and 7- log reduction in Salmonella for poultry. (BCCDC, 2014)

Table 3 - Internal temperature holding times for meats and poultry for salmonella destruction

\begin{tabular}{|c|c|c|c|}
\hline \multicolumn{2}{|c|}{$\begin{array}{l}\text { Temperature to equilibrate and } \\
\text { hold foods for sous vide heating }\end{array}$} & \multicolumn{2}{|c|}{$\begin{array}{l}\text { Amount of time to hold foods to } \\
\text { achieve full sous vide pasteurization }\end{array}$} \\
\hline $\begin{array}{c}\text { Degrees } \\
\text { Centigrade }\left({ }^{\circ} \mathrm{C}\right)\end{array}$ & $\begin{array}{c}\text { Degrees } \\
\text { Fahrenheit ( }\left({ }^{\circ} \mathrm{F}\right)\end{array}$ & $\begin{array}{c}\text { Meats } 2,21 \\
\text { 6.5- } \log _{10} \text { lethality }\end{array}$ & $\begin{array}{c}\text { Poultry } 6,24 \\
\text { 7.0- } \log _{10} \text { lethality }\end{array}$ \\
\hline 54.4 & 130 & $112 \mathrm{~min}$ & \multirow{10}{*}{$\begin{array}{l}\text { Sous vide } \\
\text { cooking below } \\
60^{\circ} \mathrm{C} \text { is } \\
\text { not } \\
\text { recommended }\end{array}$} \\
\hline 55.0 & 131 & 89 & \\
\hline 55.6 & 132 & 71 & \\
\hline 56.1 & 133 & 56 & \\
\hline 56.7 & 134 & 45 & \\
\hline 57.2 & 135 & 36 & \\
\hline 57.8 & 136 & 28 & \\
\hline 58.4 & 137 & 23 & \\
\hline 58.9 & 138 & 18 & \\
\hline 59.5 & 139 & 15 & \\
\hline 60.0 & 140 & 12 & $16.9 \mathrm{~min}$ \\
\hline 60.6 & 141 & 9 & 15.4 \\
\hline 61.1 & 142 & 8 & 13.9 \\
\hline 61.7 & 143 & 6 & 12.4 \\
\hline 62.2 & 144 & 5 & 10.8 \\
\hline 62.8 & 145 & 4 & 9.3 \\
\hline 63.3 & 146 & $169 \mathrm{sec}$ & 7.8 \\
\hline 63.9 & 147 & 134 & 6.3 \\
\hline 64.4 & 148 & 107 & 4.7 \\
\hline 65.0 & 149 & 85 & 3.2 \\
\hline 65.6 & 150 & 67 & 1.7 \\
\hline 66.1 & 151 & 54 & 1.5 \\
\hline 66.7 & 152 & 43 & 1.4 \\
\hline 67.2 & 153 & 34 & 1.2 \\
\hline 67.8 & 154 & 27 & 1.1 \\
\hline 68.3 & 155 & 22 & $54 \mathrm{sec}$ \\
\hline 68.9 & 156 & 17 & 48 \\
\hline 69.4 & 157 & 14 & 42 \\
\hline 70.0 & 158 & 0 & 30 \\
\hline 70.6 & 159 & 0 & 24 \\
\hline 71.1 & 160 & 0 & 12 \\
\hline
\end{tabular}

In this table, temperature to equilibrium means the internal temperature of food reaches to the temperature of water bath. So, based on this table, when a meat is thoroughly cooked to $55^{\circ} \mathrm{C}$, it must be kept at that temperature for at least 89 minutes to achieve 6.5 log reduction requirement.

\section{Role and Responsibilities}

EHOs have the responsibility to ensure the safety of food. However, a study has pointed out that inspection alone can not guarantee that food is safe for consumption. (Snyder, 2004) In terms of protecting public health and maintaining a high standard of food hygiene, the chefs play the most important role in ensuring the safety of food in their food premises. With proper training and education, they should know all the potential health hazards in their recipes and they need to prepare a written food safety plan for both EHOs and their employees. 
Sous vide cooking is a relatively new cooking style to many food workers. Therefore, it is also chefs' duty to train their employees, ensuring that food safety plan is understood and followed.

\section{Conclusion}

The purpose of this study was to assess knowledge and training of sous vide cooking chefs. Recently, guidelines for sous vide restaurants in BC have been developed and released to help chefs prepare sous vide food in a safe manner as well as to guide EHOs while inspecting sous vide restaurants. Using the guidelines as standards, this study assessed and compared knowledge and training of chefs and EHOs who have read sous vide guidelines and received training to those who have not.

\section{Methods:}

Based on the sous vide cooking guidelines for BC developed by the BCCDC, an online survey was created to assess chef and EHO's knowledge of sous vide. (BCCDC sous vide working group, 2014) The survey contains 28 questions, divided into four parts. Part one contains five demographic questions, asking about participants' general background such as the number of years of working experience, a selfassessment of sous vide safety knowledge, where sous vide was learnt, and working locations. In part two and part three, ten True/False (T/F) questions and seven multiple-choice questions were designed to test participants' general knowledge and understanding of sous vide cooking. These questions covered various aspects, including definition, microbiological hazards, time and temperature control, equipment usage, and food safety practices. Participants could score one point for every correct answer in $\mathrm{T} / \mathrm{F}$. Incorrect answers scored no points. In this section, the highest possible score was 10 .

In the multiple-choice section, from question one to five, each question had one best answer (5 points) and one second best answer (3 points). Only one answer could be selected from each question. In questions six and seven, there were more than one correct answer and participants were asked to choose all that applied. Every correct answer selected was worth one point. Selecting an incorrect answer scored no point. The highest possible score in this part was 28.

In part four, there were two sets of questionnaires, with six questions apiece. The first set was designed for restaurant workers to selfreport their sous vide cooking practices and the second set was designed for EHOs to selfreport their sous vide inspection practices. A 5point likert-type rating scale, ranging from one "never" to five "always", was used to indicate frequencies of each sous vide safety practice or inspection practice. The highest possible score was 30. At the end of survey, participants could choose to enter a draw for one of five free probe thermometers or coffee cards provided by BCCDC.

With the help from Chef Rahal, Chairman of BC Chef's Association, the online survey was distributed nationally to other chefs through Chefs Quarterly magazine in December 2014. In $\mathrm{BC}$, since most restaurants that practice sous vide cooking style were located in lower mainland region, the online survey was also distributed to EHOs and restaurant workers in this region through the $\mathrm{VCH}$ newsletter as well as the FHA newsletter. Both newsletters were released during January 2015. Both processes of responses collection ended on February 28, 2015. To obtain more data from chefs, the survey link was also distributed to culinary students at Vancouver Community College through Chef Tobias MacDonald.

All data were recorded and transferred onto Google Sheets automatically by Google Docs. Using the instructions online, separate sheets were developed to sort out data and calculate scores in each part of the survey (Office, 2014). These data would then be transferred to NCSS for further analysis and interpretation.

\section{Reliability and validity of measures}


To increase the reliability, the same survey was sent BCCDC, both health authorities, and Chefs' Quarterly magazine for publishing. This ensured that all participants were examined with the same standards. To increase the validity of measures, all questions were created based on BCCDC's Guidelines for Restaurant Sous Vide Cooking Safety in BC (Sous Vide Working Group, 2014). All questions had been reviewed by the student researcher and, then, were re-edited based on feedback from two BCCDC food specialists and BCCDC-invited environmental health officers, . To further enhance reliability and validity of measures, pilot tests were conducted

\section{Inclusion and Exclusion}

The survey was open to all EHOs and all chefs. Participants included those with a range of sous vide knowledge: they may have read the sous vide guidelines or attended a sous vide lecture, or did not read the guidelines or had limited prior knowledge of sous vide. Further, participants included those with a range of sous vide experience: EHOs who have/have not inspected sous vide premises, and chefs who have/have not practiced sous vide style cooking. The only persons excluded from analyses were those who self-identified as other.

\section{Ethical consideration}

A description of the nature of the study, all activities involved, and the duration of the study appeared in the cover letter as well as on the first page of the survey online. An invitation letter was provided to all participants. An ethical approval was obtained from the instructor at BCIT and appeared in the cover letter.

\section{Results}

Sixty-five individuals participated on the online survey, including EHOs $(69.3 \%, n=45)$, chefs $(23 \%, n=15)$ and others $(7.7 \%, n=5)$. Since the focus of this study were EHOs and chefs, all data were classified into two large groups, group EHO and group chefs. To better compare the knowledge difference between those who have the read the guidelines to those who have not, each large group was further dived into two small groups. So, group EHO became EHO G (have read the guidelines) and EHO N/G (have not read the guidelines). Group chefs became Chefs $G$ (have read the guidelines) and chefs N/G (have not read the guidelines).

\section{Descriptive results}

The experience levels for EHO surveyed were distributed almost equally while most chefs who completed this survey had more than 10 years of experience.

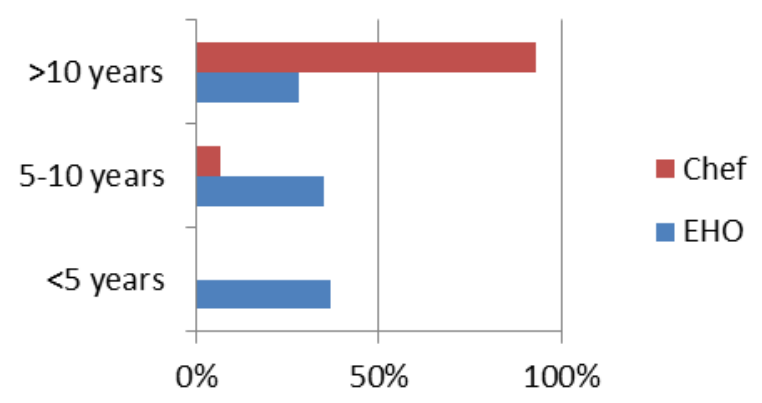

Fig. 2 Experience of survey participants

In term of self-assessed sous vide safety knowledge, more than 50 per cent of EHOs reported to have "Moderate" knowledge level and more than 60 per cent of chefs reported to have "Good” sous vide safety knowledge based on self-assessment.

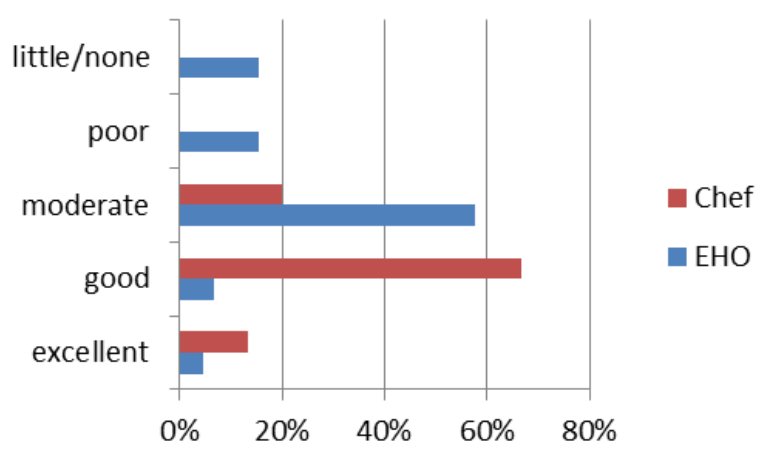

Fig. 3 Self assessed sous vide knowledge of participants

\section{True and False}

Average scores from all four groups when answering true and false questions were close. As shown in figure 3 , the average scores of those who had read the guidelines were 6.9 (EHO) and 6.6 (Chefs). The average scores of those 
who had not read the guidelines were 6.5 (EHO) and 6.4 (Chef).

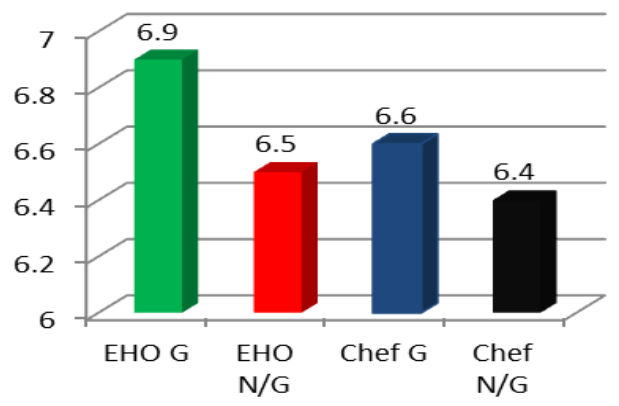

Fig. 4 The average score of each group in T/F

\section{Multiple Choice}

In the multiple choice part, the highest possible score was 28. EHO $G$ was able to outscore EHO N/G by almost 8 points in this part. However, the average score of Chef $G$ (17) was very close to that of Chef N/G (16.9).

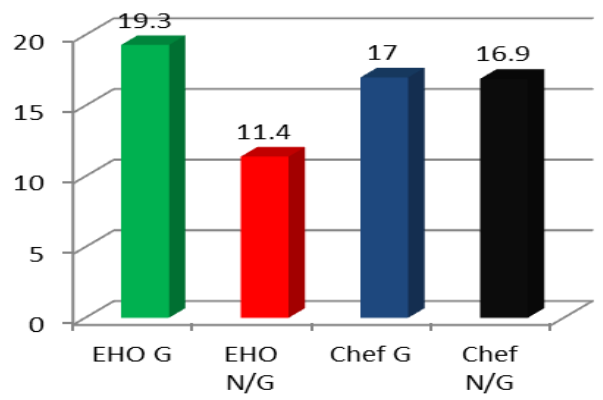

Fig. 5 The average score of each group in multiple choice

\section{Inspection/Cooking Practices}

The sous vide inspection/cooking practice part was only completed by EHOs who inspect sous vide restaurants in their districts and chefs who practice sous vide cooking in their food establishments. In this survey, 11 EHOs and 12 chefs completed this part. The percentage of EHO and chefs from each group that checked either five (always) or four (most of time) were recorded and displayed in figure 6 and 7 below.

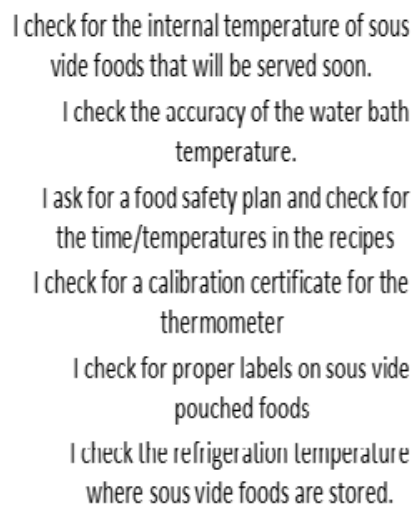

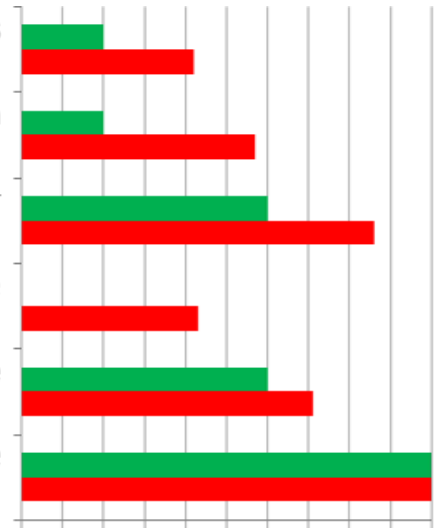

$0 \% 10 \% 20 \% 30 \% 40 \% 50 \% 60 \% 70 \% 80 \% 90 \% 100 \%$
Fig. 6 EHOs' sous vide inspection practice performing activity always or most of time time.

In figure $6, \mathrm{EHO} \mathrm{G}$ had higher percentage in most practices than EHO N/G had. This meant EHOs who read the guidelines were more likely to frequently check for the internal temperature of sous vide foods, water bath temperature, time/temperature in the recipes, calibration of thermometer and proper labels on sous vide pouched foods than EHOs who never read the guidelines.

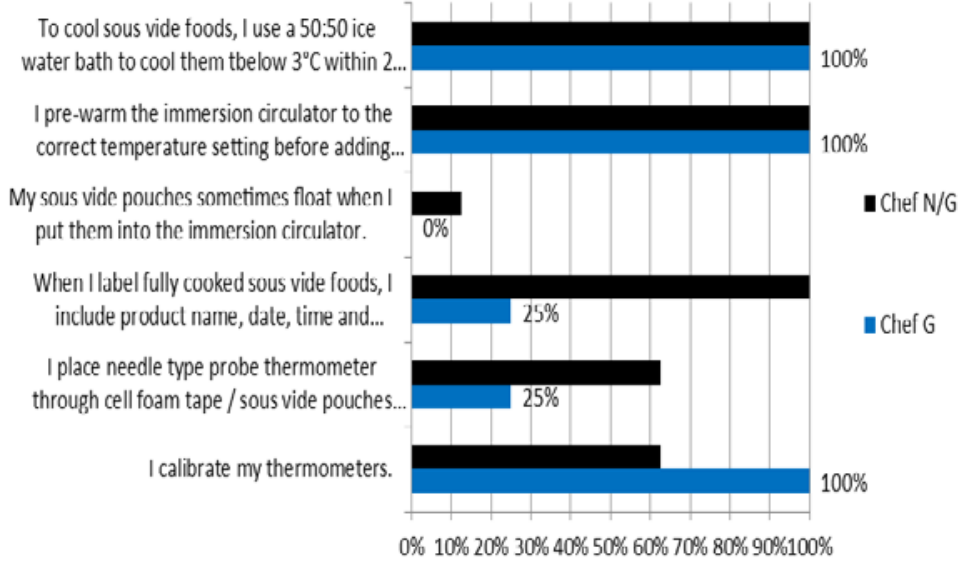

Fig. 7 Chefs sous vide practices performing activity always or most of the time

As shown in figure 7, chefs who never read the guidelines were more likely to find their sous vide pouches float in the immersion circulator, to label their fully cooked sous vide foods with name, date and discard date, and to place needle type probe thermometer through cell foam tape for measuring internal temperature at the thickest point. However, chefs who read the guidelines were more likely to calibrate their thermometers. 


\section{Inferential results}

Using NCSS, these data were assessed with two-sample T-test.

Since no study had been conducted on this topic, a two-tailed test was used. The $\mathrm{H}_{0}$ of this study was that the average score of EHOs/chefs who had read the guidelines would equal to the average scores of EHOs/chefs who had not read the guidelines. The $\mathrm{H}_{\mathrm{a}}$ was the average score of EHOs/chefs who had read the guideline would not equal to the average score of EHOs/chefs who had not read the guidelines.

With regards to results from EHO G vs. EHO N/G, the normality tests indicated that all results were "Can't reject normality" meaning that the normality assumption was met. Result of Equal-Variance test were "Cannot reject equal variances” in all three parts. Since both assumptions had been met, result from EqualVariance T-Test section, were read.

Result of the T/F test indicated that the difference between EHO G and EHO N/G was not significant ( $\mathrm{p}=0.43925, t$-test). $\mathrm{H}_{\mathrm{o}}$ could not be rejected. However, since the power of this test was only 0.11897 , it was very likely that chance played a role in this finding, resulting $\beta$ error.

Based on the multiple choice test, the average score of EHO $G$ was significant higher than that of EHO N/G (8 points; $\mathrm{P}=0.00028, t$-test). $\mathrm{H}_{\mathrm{o}}$ was rejected. The power of this test was 0.972 , indicating that chance unlikely played a role in this finding.

The same procedure was also carried out for analyzing the results from Chef $G$ vs. Chef $\mathrm{N} / \mathrm{G}$ in part two (T/F) and three (Multiple choice) of the survey. Since both assumptions were met, a parametric test was used to interpret the data. According to the test, in part two ( $\mathrm{p}=0.79878, t$-test) and three $(\mathrm{p}=0.97, t$-test $)$, differences between Chef $G$ and Chef N/G were not statistically significant. Hence, $\mathrm{H}_{\mathrm{o}}$ was not rejected. However, the powers in both part two (0.05671) and part three (0.05) were small, indicating chance played a role in the finding of these two parts, and causing $\beta$ error. Determining the cause for the difference between EHO G and EHO N/G in multiple choice

There was a significant difference between EHO G and EHO N/G in multiple choice section. To assess whether this knowledge difference was contributed solely by the sous vide guidelines, results of questions in multiple choice (including both average and mode) from both groups were listed and compared in Table 5.

Table 5 Multiple choice scores (average and mode) from both EHO G \& EHO N/G

\begin{tabular}{|c|c|c|c|c|}
\hline \multirow[t]{2}{*}{ Question } & \multicolumn{2}{|c|}{ EHO G } & \multicolumn{2}{|c|}{ EHO N/G } \\
\hline & $\begin{array}{l}\text { Avg. } \\
\text { (out of 5) }\end{array}$ & Mode & $\begin{array}{l}\text { Avg. } \\
\text { (out of 5) }\end{array}$ & Mode \\
\hline $\begin{array}{l}1 \text { The best } \\
\text { practice for } \\
\text { cooling sous } \\
\text { vide foods }\end{array}$ & 4 & 5 & 2.4 & 0 \\
\hline $\begin{array}{l}2 \text { The best } \\
\text { practice for } \\
\text { chilled fully } \\
\text { cooked sous } \\
\text { vide foods is to } \\
\text { use for service } \\
\text { within }\end{array}$ & 4.2 & 5 & 2.2 & 0 \\
\hline $\begin{array}{l}3 \text { Docu- } \\
\text { mentation for a } \\
\text { sous vide reci- } \\
\text { pe should in- } \\
\text { clude }\end{array}$ & 3.1 & 3 & 2.3 & 3 \\
\hline $\begin{array}{l}4 \text { The best } \\
\text { way to deter- } \\
\text { mine how to } \\
\text { find out how } \\
\text { long to cook } \\
\text { sous vide style } \\
\text { foods is to }\end{array}$ & 4.2 & 5 & 2.4 & 0 \\
\hline $\begin{array}{l}5 \text { The } \\
\text { danger zone } \\
\text { for sous vide } \\
\text { style cooked } \\
\text { foods is best } \\
\text { described as }\end{array}$ & 2.8 & 5 & 1.5 & 0 \\
\hline
\end{tabular}

Each question had a best answer (5 points), one or two second best answers (3 points), a third best answer (1 point), a few wrong answers (no point) and "Don't know" (no point). As shown in Table 5, most EHOs who read the guidelines were able to identify the best answers (5 
points) more often on four out of five knowledge questions, scoring on average 30\% higher than the other group. This table also showed that EHOs who never read the guidelines had trouble on identifying the best answers. In fact, after carefully reviewing all their answers, these EHOs often selected the wrong answers (0 point) or "Don't know" (0 point) in most questions. This reflected the lack of sous vide knowledge in EHO N/G. These results suggested that the sous vide guidelines were able to provide EHOs with sufficient sous vide knowledge to answer questions about sous vide safety risk appropriately.

Other factors, such as level of experience, selfassessed knowledge and place of employment could potentially also contribute to such result. Because of that, these factors were also examined. To determine if there was an association between years of experience and multiple choice score, a Chi Square test was carried out. Results are shown below.

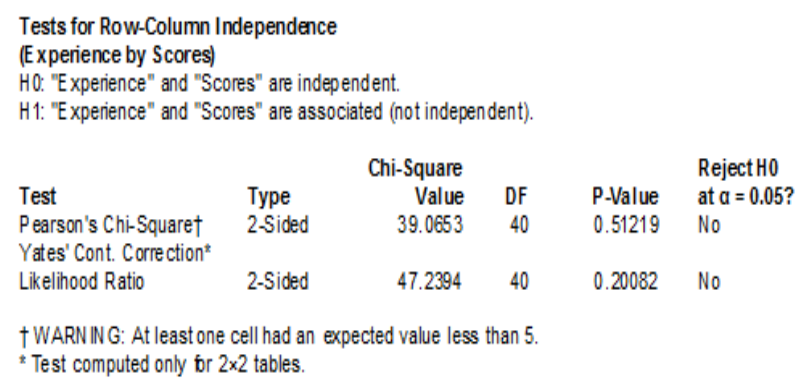

Fig. 8 Results of Chi Square test - Experience vs scores

Results indicated that years of experience and multiple choice scores were actually independent. There was no association between these two variables.

With regard to self-assessed knowledge, more than $50 \%$ of participants from both groups reported to have 'Moderate' sous vide knowledge (EHO G 61\%, EHO N/G 56\%). However, in terms of knowledge level distributions, there were some differences between these two groups. 27\% of participants from EHO G reported to have 'Good' or 'Excellent' knowledge level and only $10 \%$ reported to have 'Poor' or 'Not much knowledge of sous vide cooking'. From EHO N/G, no one report- ed to have either 'Excellent' or 'Good' knowledge level, but, $44 \%$ of participants from this group reported to have either 'Poor' or 'Not much knowledge of sous vide cooking'. This self-assessed sous vide safety knowledge was a subjective self-assessment. It did not really represent the true knowledge level. Instead, this result was associated mostly with participants' previous sous vide training or education experience, such as cook books, online course, or other related regulations.

To assess whether these previous experiences could affect multiple choice scores another Chi Square test was conducted to examine association between these two variables. Results are shown below.

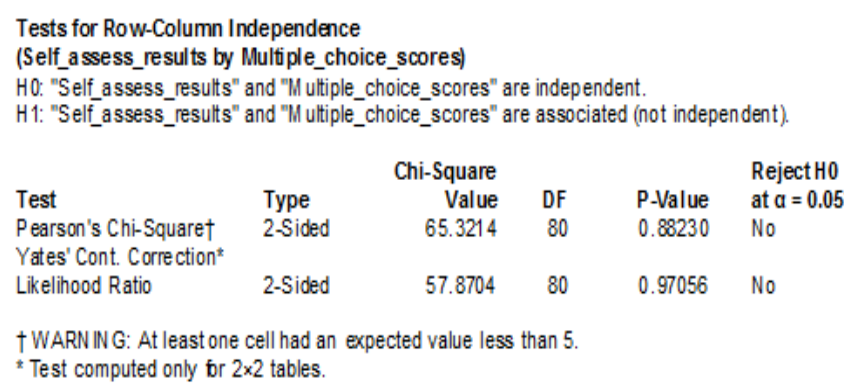

Fig. 9 Results of Chi Square test - Self-assessed results vs. multiple choice score

Result of Chi Square showed that there was no association between self-assess results and scores. This meant previous knowledge actually did not contribute to the score difference between EHO G and EHO N/G in the multiple choice part.

The last factor that could affect the scoring was employment location. Most EHOs who did the survey were from BC (EHO G 94\%, EHO N/G $82 \%)$. That meant, in terms of location, both groups were very similar. So, it was unlikely that this factor could affect our results either.

\section{Discussion:}

\section{Comparison of knowledge level between EHO $G$ and $E H O N / G$}

In the multiple choice part, EHOs who read the guidelines (EHO G) were able to get better score than EHOs who did not read the guidelines (EHO N/G) did in the multiple choice section. This result indicated that EHO G had better knowledge about sous vide cooking than 
EHO N/G did. In terms of knowledge level, having proper training or education do matter. This result is consistent with other study that showed courses, such as FOODSAFE training program, were able to help food handlers get better scores in food safety knowledge test (Mclntyre, 2013).

Our results also showed other factor such as years of experience, previous knowledge from other sources, or employment location did not contribute to knowledge difference between this two groups. This finding, however, was different from results of another study which showed "a [positive] relationship was observed between years of food service experience and knowledge of basic food safety...” among food service managers (Lynch, 2003).

\section{Comparison of inspection and cooking prac- tices}

In terms of inspection practices, there was difference between these EHO G and EHO N/G.

Our results showed EHO who had read the guidelines were more likely to frequently check for temperatures and cooking periods. Inspecting time and temperature were essential parts of a good inspection. In other words, EHO G had overall better inspection practices. This result was consistent with another study that showed education and training could improve food safety inspection scores (Riben, 1993)

In terms of cooking practices, there was also difference between chef $G$ and chef N/G too. Higher percentage of chefs who never read the guidelines frequently found their sous vide pouch floating in the immersion circulator. This was actually not a good sign as it indicated insufficient vacuum packaging - excessive air left in the pouch. The excessive air could reduce heat transfer resulting undercook meat. No chef who read the guidelines frequently found such thing occurred in their facility. This result was consistent with another study that showed training and education could make school meal services conform to good practices (da Cunha, 2013) The next two practices, including proper labelling and checking temperature at the thickest point, were good practices.
However, in the two practices, our results showed higher percentage of chefs who never read the guidelines actually frequently did these two things. Only 25\% of chefs who read the guidelines had these practices done frequently. Both proper labelling and the appropriate method of measuring internal temperature were important to food safety. They should be carried on regularly on a routine basis.

\section{$S V$ is a new technique and having SV guide- lines are necessary.}

The survey was distributed to all the chefs in BC through Chefs Quarterly magazine, BC chef association, and culinary school in Vancouver Community College. After almost two months of data collection, the total number of responses collected from chefs was small $(\mathrm{n}=$ 17). One major reason for having such low number of responses could be that there is really not many sous vide restaurants in $\mathrm{BC}$ as it is still a relatively new cooking technique. Indeed, the technique of sous vide was first introduced into BC during 1970s, but it was not popular until early 2000s (Pak, 2004). Most of sous vide restaurants in $\mathrm{BC}$ are concentrated in the Lower Mainland and there are about 34 sous vide restaurants within this region (Yelp, 2015). This shows that, comparing to other cooking techniques, only a few chefs have mastered this new technique.

Despite the fact that sous vide is relatively new and not many cooks understand how it actually works, sous vide food is becoming more popular. Since the late-2000s, more restaurants are willing to practice sous vide (Baldwin, 2012). Without having proper standards, food safety will become a potential issue. To ensure the safety of this relatively new technique, it is necessary to study and understand the science behind it. This can help reduce risk of foodborne illness related to sous vide. As a matter of fact, recently, various government agencies around the world have developed guidelines or created new regulations to achieve such this purpose. For example, in 2009, in the FDA Food Code, the US FDA listed criteria focusing specifically on the processing of sous vide food (FDA, 2009). In 2012, both New South Wales 
Food Authority and South Oxfordshire district council released their sous vide guidelines (NSW Food Authority, 2012 \& South Oxfordshire Food and Safety Team, 2012). Last fall, $\mathrm{BC}$ also developed its own guidelines for sous vide restaurants. (BCCDC sous vide working group, 2014)

It is hard to comment on the effectiveness of these sous vide guidelines and regulations since no study has been done to evaluate these documents. However, there is no doubt that the more we know about sous vide, the better we will be at managing the risk as well as handling sous vide related outbreak. Thus, having the sous vide guidelines is necessary

\section{Limitations}

There were several limitations in this study. The first limitation was the sample size. Sample sizes were important for drawing significant conclusion for the study. In this study, two-sample $t$-test was performed for examining if the knowledge difference between two groups was significant. One of the requirements of a t-test analysis is to have at least 30 samples in each group. Unfortunately, in this study, most groups were not able to meet this requirement. Because of that, most results showed high $P$ values with low power (Appen$\operatorname{dix} A, C$ and $D$ ), indicating possible $\beta$ errors in these results. Thus, they were not valid for drawing a conclusion for this study.

There were couple of reasons for having such small number of inputs. One of them could be the method. The method employed in this study was an online survey which was developed by Google Docs and was distributed to the target groups mainly through emails and BCCDC website. A disadvantage of this method was limited sampling. This could be attributed to respondents' availability as well as their attitudes towards online surveys. The second reason could be associated with the number of sous vide food establishments in BC. The lowest inputs were observed in the last part of the survey. This part was designed for either EHOs who inspected sous vide restaurants or chefs who practiced sous vide cooking. Because of the fact there were not that many sous vide restaurants in BC, only a few respondents completed this part.

Since the guidelines were developed for EHOs and chefs in $\mathrm{BC}$, the main target audiences of this study were EHOs and chefs from BC. Results in this study reflected mostly EHOs' and chefs' sous vide knowledge level as well as inspection and cooking practices in this province. Other province or other countries may have different guidelines or regulations that address sous vide food safety. Therefore, extrapolating the finding in this study nationwide or to other countries may not be possible.

\section{Recommendations}

The guidelines are great tool for learning and understanding about sous vide. It is strongly recommended for EHOs, especially those who inspect sous vide food premise in their districts, to study the guidelines or use them as supportive materials while conducting inspection.

\section{Future research suggestions}

To better evaluate chefs' knowledge, a different method may be required.

To better evaluate cooking and inspection practices, onsite interview and observation may be required.

\section{Conclusion}

Results from this study show that EHOs who have read the sous vide guidelines are able to obtain higher scores in the multiple choice part. Also, a higher percentage of them have better overall inspection practices than EHOs who have never read the guidelines. When comparing chefs who have the guidelines with chefs have never the guidelines, minor differences are noticed in the cooking practices section and no significance difference is observed in the knowledge section.

Based on these results, it is clear that the guidelines could help enhance EHOs' sous vide knowledge level, providing them with a better understanding of risks associated with this cooking method. This can benefit EHOs when 
they inspect a sous vide restaurant, educate operators, or even investigate a sous vide-related outbreak.

\section{Acknowledgement}

The author would like to thank Helen Heacock and Lorraine McIntyre for providing support and guidance for conducting this study as well as writing this research paper.

\section{Competing Interest}

The authors declare that they have no competing interests. 


\section{Reference:}

Agarwal, A. (2014) Why Forms in Google Docs are perfect for Creating Online Surveys. Retrieved from: http://www.labnol.org/software/google-docs-forms-for-surveys/10056/

Baldwin, D. E. (2012). Sous vide cooking: A review. International Journal of Gastronomy and Food Science, 1(1), 15-30.

BCCDC (2012) BC Annual Summary of Reportable Disease 2012. Page 15. Retrieved from :http://www.bccdc.ca/NR/rdonlyres/F30377E3-D33E-4755-B3F4-6844E0 1BD678/0/FinalAR2012.pdf

BCCDC Sous Vide Working Group (2014) Guidelines for restaurant sous vide cooking safety in BC. Retrieved from: http://www.bccdc.ca/NR/ rdonlyres/1692F859- D7A8-4B19-8841- C8 418 DE F412 C/0 /SV Guidelines_FinalforWeb.pdf

Christensen L, Gunvig A, Tørngren MA, Aaslyng MD, Knøchel S, Christensen M. Sensory characteristics of meat cooked for prolonged times at low temperature. Meat Science. 2012;90(2):4859.

Canadian Food Inspection Agency. Meat and poultry products. Manual of procedures. Chapter 4. Cooking time/temperature tables. 2010 [cited 2013 Jun 24]; Available from: http://www.inspection.gc.ca/english/fssa/meavia/man/ch4/annexde.shtml\#t1.

da Cunha, D. T., Fiorotti, R. M., Baldasso, J. G., de Sousa, M., Fontanezi, N. M., Caivano, S., ... \& Camargo, M. C. R. (2013). Improvement of food safety in school meal service during a longterm intervention period: a strategy based on the knowledge, attitude and practice triad. Food Control, 34(2), 662-667.

Duffy, G., Cummins, E., Nally, P., O’Brien, S., \& Butler, F. (2006). A review of quantitative microbial risk assessment in the management of Escherichia coli O157: H7 on beef. Meat science, 74(1), 76-88.

Frank, D. N., Feazel, L. M., Bessesen, M. T., Price, C. S., Janoff, E. N., \& Pace, N. R. (2010).The human nasal microbiota and Staphylococcus aureus carriage. PLoS One, 5(5), e10598.

Francois J. Sous vide cooking a blog about cooking with low temperatures. 2013 [cited 2014 Apr 14]; Available from: http://www.sousvidecooking.org/.

Food and Drug Administration. FDA Food Code. College Park, MD: U.S. Department of Health and Human Services,; 2013 [cited 2014 January 6]; Available from:http://www.fda.gov/Food/GuidanceRegulation/RetailFoodProtection/FoodCode/ucm37427 5.htm.

Henderson (2012) Online Survey Tools: Which One is Best for You?Retrieved from:ht tp://whinot.com/blog/2012/4-online-surve y-tools-whi ch-one- is-best-for-you/

Horowitz, B. Z. (2005). Botulinum toxin. Critical care clinics, 21(4), 825-839.

Hintze, J. (2012). NCSS 8. NCSS, LLC. Kaysville, Utah, USA. Retrieved from: www.ncss.comhttp://www.ncss.com/software/ncss/ 
Juliao, P. C., Maslanka, S., Dykes, J., Gaul, L., Bagdure, S., Granzow-Kibiger, L., ... \& Barzilay, E. J. (2013). National outbreak of type a foodborne botulism associated with a widely distributed commercially canned hot dog chili sauce.Clinical infectious diseases, 56(3), 376-382

Keller T, Benno J, Lee C, Rouxel S. Under Pressure: Cooking Sous Vide. New York: Artisan / Workman Publishing Company; 2008.

Logsdon J. (2014) Modernist Cooking Made Easy: Sous Vide. Retrieved from: http://www.modernistcookingmadeeasy.com/sample/Sous-Vide-Sample.pdf

Lynch, R. A., Elledge, B. L., Griffith, C. C., \& Boatright, D. T. (2003). A comparison of food safety knowledge among restaurant managers, by source of training and experience, in Oklahoma County, Oklahoma. Journal of environmental health, 66(2), 9-14

McKenney, P. T., Driks, A., \& Eichenberger, P. (2012). The Bacillus subtilis endospore: assembly and functions of the multilayered coat. Nature Reviews Microbiology, 11(1), 33-44.

McIntyre, L., Vallaster, L., Wilcott, L., Henderson, S. B., \& Kosatsky, T. (2013). Evaluation of food safety knowledge, attitudes and self-reported hand washing practices in FOODSAFE trained and untrained food handlers in British Columbia, Canada. Food Control, 30(1), 150-156.

Muise, J.\& Olson, K. (2008) Face to face interview. Retrieved from: http://web.viu.ca/rtri/Face\%20to\%20Face.pdf

National Advisory Committee on Microbiological Criteria for Foods. Response to the Questions Posed by the Food and Drug Administration and the National Marine Fisheries Service Regarding Determination of Cooking Parameters for Safe Seafood for Consumers. Journal of Food Protection. 2008;71(6):1287-308

NSW Food Authority (2012) Sous vide: Food safety precautions for restaurants. Retrieved from: http://www.foodauthority.nsw.gov.au/_Documents/science/sous_vide_food_safey_precautions.p df

Rasko, D. A., Webster, D. R., Sahi, J. W., Bashir, A., Boisen, N., Scheulz, F., ... \& Waldor, M. K. (2011) Origins of the E. Coli strain causing an outbreak of hemolytic-uremic syndrome in Gemany. New England Journal of Medicine, 365(8), 709 - 717.

Ruiz J, Calvarro J, Sanchez Del Pulgar J, Roldan M. (2013) Science and Technology for New culinary Techniques. Journal of culinary Science \& Technology. 2013/03/01; 11(1):66-79

Riben, P. D., Mathias, R. G., Campbell, E., \& Wiens, M. (1993). The evaluation of the effectiveness of routine restaurant inspections and education of food handlers: critical appraisal of the literature. Canadian journal of public health= Revue canadienne de sante publique, 85, S56-60

Ryan KJ, Ray CG (editors) (2004). Sherris Medical Microbiology (4th ed.). McGraw Hill. pp. 3628. ISBN 0-8385-8529-9 
Sivapalasingam, S., Friedman, C. R., Cohen, L., \& Tauxe, R. V. (2004). Fresh produce: a growing cause of outbreaks of foodborne illness in the United States, 1973 through 1997. Journal of Food Protection ${ }^{\circledR}, 67(10), 2342-2353$.

Snyder Jr, O. P., Novak, J. S., Sapers, G. M., \& Juneja, V. K. (2004). HACCP and regulations applied to minimally processed foods. Microbial safety of minimally processed foods, 127-150.

South Oxfordshire Food \& Safety Team (2012) Guidance on sous vide cooking. Retrieved from: www.southoxon.gov.uk/node/9550

SurveyMonkey (2013) Retrieved from https://www.surveymonkey.com/

Office (2014) If function. Retrieved from: http://office.microsoft.com/en-ca/e xcel-help/if-functionHP010342586.aspx

The Culinary Institue of America.(2011) Sous Vide. The Professional Chef. Hoboken, New Jersey: John Wiley \& Sons, Inc. p. 548-52

Wijnands, L., Dufrenne, J., Zwietering, M. H., and Leusden, F. "Spores from mesophilic Bacillus cereus strains germinate better and grow faster in simulated gastro-intestinal conditions than spores from psychrotrophic strains.” International Journal of Food Microbiology. 2006. Volume 112. Issue 2. p. $120-128$

US CDC http://www.cdc.gov/foodborneburden/2011-foodborne-estimates.html 